\title{
ERRATUM
}

\section{Erratum to: A case with vesicouterine fistula: mini review}

\author{
Mehmet Onur Karaltı • Şivekar Tinar • \\ Nilgün Turhan Öztürk · Deniz Can Öztekin
}

Published online: 12 January 2013

(c) Springer-Verlag Berlin Heidelberg 2013

Erratum to: Arch Gynecol Obstet (2012) 285:667-670

DOI 10.1007/s00404-011-2188-z

The last author's family name should read as Öztekin and not Öztürk as in the published version. The correct author group is given below.

Mehmet Onur Karaltı · Şivekar Tınar · Nilgün Turhan Öztürk · Deniz Can Öztekin

The online version of the original article can be found under doi:10.1007/s00404-011-2188-z.

M. O. Karaltı ( $\square)$

Köyceğiz State Hospital, Gelişim Mah. Köyceğiz,

48800 Muğla, Turkey

e-mail: mdronur@hotmail.com

Ş. Tınar · D. C. Öztekin

Eagen Maternity and Health Teaching Hospital,

İzmir, Turkey

N. T. Öztürk

Department of Obstetrics and Gynecology,

Faculty of Medicine, Muğla University,

Muğla, Turkey 